ACTA UNIVERSITATIS LODZIENSIS

FOLIA LITTERARIA POLONICA 4(30) 2015

http://dx.doi.org/10.18778/1505-9057.30.04

Katarzyna Szumska*

\title{
Proverbes dramatiques w polskiej dramaturgii XIX wieku
}

Proverbe dramatique lub też comédie proverbe - 'przysłowie dramatyczne', gatunek mało zauważany w polskiej dramaturgii dziewiętnastowiecznej. Jako forma teatralna powstał we Francji na początku XVII, a rozwinął się w drugiej połowie XVIII stulecia. Początków można szukać znacznie wcześniej - przysłowiowe tytuły pojawiają się u renesansowych hiszpańskich i angielskich twórców dramatu ${ }^{1}$, ale jego źródło tkwi w grach towarzyskich (jeux de société - jeux des proverbes, proverbe improvisé), bardzo popularnych w literackich salonach epoki Oświecenia. W trakcie zabawy zapisywano przysłowia i improwizowano scenki, tworzono małe spektakle w stylu komedii dell'arte, na podstawie których należało odgadnąć dane powiedzenie. Pierwsze sztuki wykorzystujące przysłowia pojawiły się we francuskich teatrach salonowych na początku XVII wieku. W 1616 roku widzowie teatru w rezydencji Hôtel de Bourgogne mogli obejrzeć La Comédie des proverbes Adriena de Montluca, gdzie dialogi w całości oparto o przysłowia i powiedzonka. W 1642 roku ukazały się gry domowe Charles'a Sorela, La Maison des jeux, zawierające wskazówki do zabaw improwizowanych, a w 1654 roku królewska rodzina wraz z członkami dworu odegrała Ballet des proverbes Isaaca de Benserade’a, który każdemu „aktorowi” przydzielił do odegrania inne przysłowie ${ }^{2}$.

Genologiczne reguły tego drobnego gatunku przypisuje się Louisowi Carrogisowi de Carmontelle'owi, malarzowi i architektowi krajobrazu, który w 1763 roku znalazł się na dworze Ludwika Filipa, gdzie organizował przedstawienia teatralne na podstawie własnych sztuk, tworząc do nich kostiumy i dekoracje. Carmontelle miał jednak swoich prekursorów, a zwłaszcza prekursorki, z których najciekawszą

\footnotetext{
* Mgr, Uniwersytet Łódzki, Wydział Filologiczny, Instytut Filologii Polskiej, Katedra Literatury i Tradycji Romantyzmu, ul. Pomorska 171/173, 90-236 Łódź, e-mail: katarzyna_szumska@wp.pl.

${ }^{1}$ A. Nicoll, Dzieje dramatu. Od Ajschylosa do Anouilha, t. 1, tłum. H. Krzeczkowski, W. Niepokólczycki, J. Nowacki, wyd. 3, Państwowy Instytut Wydawniczy, Warszawa 1983, s. 457.

${ }^{2}$ Zob. A.C. Leboeuf, The Proverbe dramatique before Carmontelle, The University of Texas at Austin 2010, http://repositories.lib.utexas.edu/bitstream/handle/2152/ETD-UT-2010-05-1025/ LEBOEUF-DISSERTATION.pdf [dostęp: 10.11.2014].
} 
była pisarka Catherine Durand. W roku 1669 dziesięć przysłów dramatycznych (od kilku do kilkunastu scen ponumerowanych dialogów) Madame Durand zostało opublikowanych $\mathrm{w}$ drugim tomie Voyage de campagne hrabiny Murat ${ }^{3}$. $\mathrm{Na}$ końcu tomu umieszczono wykaz przysłów przeznaczonych do odgadnięcia, zilustrowanych przez określone utwory ${ }^{4}$. W latach 1690-1710 Madame de Maintenon napisała około 40 przysłów dramatycznych dla panien uczących się w założonej przez nią szkole w Saint-Cyr. Przysłowia te zostały wydane dopiero w 1829 roku$^{5}$. W dydaktyce wykorzystał tę formę również Victor Cholet, autor zbioru Petits Proverbes Dramatiques, à l'usage des jeunes gens (1837), a francuskie przysłowia dramatyczne dla dzieci tłumaczone były także na język polski ${ }^{6}$. Bezpośrednim poprzednikiem Carmontelle’a był Charles Collé (od 1748 roku główny dostawca sztuk dla teatru dworskiego księcia Orleanu), ale dopiero nadworny portrecista Ludwika Filipa nadał przysłowiu rangę utworu literackiego, rozwinął ,typową formę francuskiej salonowej comédie-proverbekrótkie, skondensowane, epigramatyczne sztuki w duchu komicznym o poważnych tonach głębszych"7. W latach 1768-1781 opublikowano jego ośmiotomowe Proverbes dramatiques, które dały impuls do powstania wielotomowej edycji ciekawych, realistyczno-satyrycznych przysłów z epoki napoleońskiej. Ich autorem był Michel Théodore Leclerq.

Szczytowym osiągnięciem tego gatunku były przysłowia dramatyczne Alfreda de Musseta zawarte w zbiorze Comédies et proverbes (1840-1854), a szczególnie pełne kontrastów Nie igra się z mitościa (On ne badine pas avec l'amour, 1834) - komedia romantyczna łącząca w sobie tragizm z komizmem i groteską, poruszająca społeczne problemy, w której konflikt - nieporozumienie pomiędzy Kamilą i Oktawem - ma tragiczny finał. Utwory Musseta, często thumaczone i wystawiane przez polskie teatry, wpłynęły na powstawanie przysłów dramatycznych w naszej literaturze, ale, z wyjątkiem twórczości Aleksandra Fredry, który był „,znakomitym kontynuatorem tradycji proverbes dramatiques" ${ }^{\prime}$ i który, niezależnie od francuskiego romantyka, wyszedł daleko poza ramy tego gatunku, żadne z nich nie osiągnęło poziomu sztuk autora Spowiedzi dziecięcia wieku.

Przysłowia dramatyczne były tłumaczone i wystawiane na deskach polskich teatrów na długo przed Mussetem. W roku 1815 w Warszawie, w 1819 we Lwowie, a w 1923 w Krakowie wystawiono trzyaktową komedię Jean-Baptiste’a Viala

\footnotetext{
${ }^{3}$ Zob. Comédies en proverbes de Madame $D^{* * *}$, w: H.-J. de Castelnau Murat, Voyage de campagne, t. 2, Paris 1734, s. 73-286.

${ }^{4}$ Tamże, s. 286.

${ }^{5}$ F. d'Aubigné Maintenon, Proverbes inédits de madame la marquise de Maintenon, publiés par M. de Monmerqué, J.-J. Blaise, Paris 1829.

${ }^{6} \mathrm{~Np}$. Robert, dramatyczne przystowie. W jednym akcie, w: Teatr dla dzieci czyli zbiór sztuk współczesnych, przekł. z fr. P.E. Leśniewski, Drukarnia Piotra Baryckiego, Warszawa 1838.

${ }^{7}$ A. Nicoll, dz. cyt., s. 457.

${ }^{8}$ M. Inglot, Komedie Aleksandra Fredry. Literatura i teatr, Ossolineum, Wrocław 1987, s. 218.
} 
Kto pierwszy, ten lepszy czyli Cztery mile drogi, w przeróbce Jana Karola Chrzanowskiego. W teatrze wileńskim w 1818 roku, a w Krakowie w 1820 roku grano jednoaktówkę Wilhelma Heinricha Brömela Kto pod kim dotki kopie, sam w nie wpada czyli Ttumaczenie praw co do stowa, która jeszcze w latach 70. XIX wieku pojawiała się w lwowskim repertuarze. Wyjątkowym powodzeniem cieszyła się komedia pomyłek o wartkiej akcji Jean-Baptiste'a Dubois Trafita kosa na kamień, w dwóch wersjach: w przeróbce Wojciecha Pękalskiego z 1804 roku i w przekładzie Konstantego Majeranowskiego z 1846 roku' . Zabawna historia przebieranek dwójki służących, Ludwiki i Teodora, od pierwszej dekady aż po lata 70. XIX stulecia gościła na deskach teatrów, m.in. Białegostoku, Krakowa i Lwowa ${ }^{10}$.

Najbliższy genezie gatunku jest Ślepiec Jana Potockiego ${ }^{11}$. Utwór ma charakter żartu salonowego. Napisany po francusku tekst odkrył w Kijowie Dominique Triaire; datował go pomiędzy rokiem 1798 a 1803. Ta komediowa miniatura prawdopodobnie została stworzona z myślą o mających zagrać główne role sześciu córkach Stanisława Szczęsnego Potockiego, właściciela zamku w Tulczynie, gdzie mieścił się teatr. Cała rzecz dzieje się w domu pani Fargeot, żony kupca z Martyniki, która czyta swoim córkom list od ojca polecający wydanie jednej z nich za mąż za jego wspólnika w interesach. Nie wiedzą, że tenże ukrywa się w przebraniu ślepca, który właśnie przybył do ich domu. Role kobiece mają przypisane konkretne umiejętności i zainteresowania: taniec, grę na klawesynie, czytanie, szydełkowanie. W „pogodnie bezmyślnej”"12, dynamicznej sztuce z morałem pojawiają się echa lektur oświeceniowych - Racine’a oraz Laury i Filona Karpińskiego. Przysłowie nie jest wyrażone wprost, ale tytułowa postać ma tu własne symboliczne znaczenie - ślepy los sprzyja dobrym, pięknym i bogatym pannom.

${ }^{9}$ Zob. rękopis egzemplarza teatralnego z Biblioteki Teatru Lwowskiego, w przekładzie K. Majeranowskiego: J.B. Dubois, (Ukarany zazdrośnik). Trafita kosa na kamień. Komedia w 1 akcie $z$ francuskiego tłomaczona przez I. Majeranowskiego, http://www.europeana.eu/portal/record/09404/id_oai_www_sbc_org_pl_24972.html [dostęp: 15.11.2014].

${ }^{10}$ Wszystkie dane repertuarowe na podstawie następujących zestawień: Bibliografia dramatu polskiego 1765-1964, t. 1-2: L. Simon, Bibliografia dramatu polskiego 1765-1939, oprac. i red. E. Heise i T. Sivert, Państwowy Instytut Wydawniczy, Warszawa 1972; K. Estreicher, Bibliografia polska XIX stulecia, wyd. 2 nowe, t. 4: D-Dramat polski, Państwowe Wydawnictwo Naukowe, Kraków 1966; A. Marszałek, Repertuar teatru polskiego we Lwowie 1864-1875, Towarzystwo Naukowe Societas Vistulana, Kraków 2003 i Repertuar teatru polskiego we Lwowie 1875-1881, Wydawnictwo Universitas, Kraków 1992; S. Pepłowski, Teatr polski we Lwowie (1780-1881), Księgarnia Gubrynowicza i Schmidta z Drukarni „Dziennika Polskiego”, Lwów 1889; Znany repertuar teatru wileńskiego wrzesień 1815-październik 1824, w: M. Witkowski, Świat teatralny młodego Mickiewicza, Państwowy Instytut Wydawniczy, Warszawa 1971, s. 281-320; A. Wanicka, Dramat i komedia Teatrów Warszawskich 1868-1880, Wydawnictwo UJ, Kraków 2011; Repertuar Starego Teatru (Teatru Krakowskiego) od 1781 do czerwca 2011 roku. Sztuki dramatyczne i operowe zespołu polskiego z lat 1781-1893, http://www.cyfrowemuzeum.stary.pl/repertuar_od_1781 [dostęp: 15.11.2014].

${ }_{11}$ J. Potocki, Ślepiec, tłum. P. Szymonowski, „Dialog” 1993, nr 8, s. 14-20.

12 Zob. M. Szpakowska, Wszystkiemu winne Oświecenie, „Dialog”, 1993, t. 38, nr 8, s. 58. 
Bliskie oświeceniowym komediom jest też przysłowie Fryderyka Skarbka ${ }^{13}$ Co głowa, to rozum ${ }^{14}$, napisane dla teatru amatorskiego, a wystawione w warszawskim Teatrze Rozmaitości w $1830 \mathrm{roku}^{15}$. Rzecz dzieje się w wiejskim domu Sędziego, który wspólnie z żoną i jej siostrą knuje intrygę, a każde z nich ponadto jeszcze własną, bez porozumienia z pozostałymi domownikami. Powikłania sytuacyjne prowadzą do finału, wytłumaczonego przez Sędziego tytułowym przysłowiem. W tym samym roku w Warszawie wyszła zabawna krotochwila ze śpiewami Każdy swój towar chwali Józefa Danielowicza (wystawiana była m.in. w Teatrze Starym w Krakowie w 1832 roku). Źródłem humoru tej jednoaktówki jest stylizowany, kwiecisty język oraz nazwiska charakteryzujące zalotników panny Julii Oszczędnickiej, których popisy i przechwałki komentowane są w przyśpiewkach.

Popularność przysłów dramatycznych na polskich scenach przypada na drugą połowę XIX wieku, szczególnie na lata 60. i 70. Można zastanawiać się nad jej przyczynami, bo z jednej strony w tle mamy doświadczenia tragicznych wydarzeń, $\mathrm{z}$ drugiej - powrót do zabaw salonowych, a w teatralnych repertuarach królują komedie i farsy. Sztuki te kierowano do określonego odbiorcy, do kształtującej się wówczas nowej klasy społecznej - mieszczańskiej inteligencji. W przysłowiach z tego okresu miejsce dramatu to najczęściej salonik lub gabinet w mieście, „skromnie, acz gustownie umeblowany”, pojawia się nowy typ bohatera - profesor, urzędnik, adwokat, a choć mamy też postaci z gminu, które z powodzeniem w swoich dramatach wprowadzał Władysław Ludwik Anczyc. Jego krótkie (trzy sceny), wierszowane, obfitujące w potoczne zwroty przysłowie Nie kladź palca między drzwi to bardzo dynamiczna, śpiewna historyjka o zazdrosnym szewcu. Bohaterów podobnej proweniencji można znaleźć w sztukach Edwarda Lubowskiego. Akcja przysłowia w dwóch odsłonach Nie wszystko złoto, co się świeci rozgrywa się w warsztacie tokarskim. To dość płaska, przewidywalna intryga z morałem, o dwóch przyjaciołach, z których jeden dostaje nauczkę, zrozumiawszy przy tym, że pieniądze nie są najważniejsze. Dużo ciekawsza jest jednoaktówka z elementami farsy Skapy dwa razy traci. Główny bohater to Zygmunt, utracjusz, który nie może doczekać się spadku po skąpym wuju (niemal molierowska postać), próbującym pozbyć się kłopotliwego siostrzeńca m.in. poprzez ożenek z... nieboszcz-

${ }^{13}$ Skarbek napisał także komedię w trzech aktach, ilustrującą przysłowie: „Strach ma wielkie oczy”. Historia miłości córki oberżysty i młodego porucznika, nieporozumień pomiędzy ojcami bohaterów a intrygantem Panem Ważnym znacznie odbiega od typowego przysłowia dramatycznego. Zob. rękopis teatralny Strach ma wielkie oczy czyli Podejrzany. Komedia $w$ trzech aktach przez Fryderyka Hr. Skarbka, Lwów 1877, http://www.sbc.org.pl/dlibra/docmetadata?id=40773 [dostęp: 10.05.2015].

14 Taki sam tytuł nosi, napisany przez Skarbka, felieton o przysłowiach w: „Pamiętnik Warszawski” 1822 , t. 2, s. 389-397.

${ }^{15}$ Przysłowie opublikowano po raz pierwszy w: F. Skarbek, Teatr Fryderyka hr. Skarbka, t. 2, Drukarnia Stanisława Strąbskiego, Warszawa 1847, s. 389-419. 
ką. Wydawałoby się, że nauczkę dostanie manipulant Zygmunt, w finale jednak to on wygrywa. Komedie te zostały opublikowane w popularnych periodykach ${ }^{16}$. Intensywny rozwój czasopiśmiennictwa w drugiej połowie wieku ułatwiał rozpowszechnianie krótkich utworów przeznaczonych dla domowej rozrywki. Przysłowia sceniczne zamieszczały, oprócz wspomnianych, m.in. „Gazeta Codzienna”"17, popularne „Echo Muzyczne, Teatralne i Artystyczne” oraz „Wieczory Rodzinne” i „Bluszcz”. W dwutygodniku „Kronika Rodzinna” znalazła się m.in. wierszowana krotochwila Gabrieli Puzyniny Trafita kosa na kamieńn ${ }^{18}$ - zabawna historia o niespełnionej pisarce, Lucynie. Bohaterka komedii, zniecierpliwiona odczytywaniem własnych tekstów przez podobnego do niej „literata”, uświadamia sobie swoje przywary: „W próżności jego widzę miłość własną" ${ }^{19}$. W sztuce znajdziemy ciekawe uwagi o epigonizmie, a w jej podsumowaniu tytułowe porzekadło:

Ciekawa rzecz jednakże, co by to wypadło

Gdyby takie w istocie dobrało się stadło?

Czyżby się poprawili wzajem, czy zabili? -

Tymczasem mam gotową treść do krotochwili.

Wezmę ją na lekarstwo autorskich omamień,

A tytuł będzie: „Kosa trafiła na kamien’” ${ }^{20}$

Powrót do ukształtowanych w epoce Oświecenia przysłów dramatycznych z ich dydaktyzmem i moralno-obyczajową problematyką oraz do dramatu mieszczańskiego zapowiadał zmiany nadchodzące w dziewiętnastowiecznej dramaturgii - m.in. komedię biedermeierowską i późniejsze wykrystalizowanie się dramatu obyczajowo-psychologicznego. Przysłowia sceniczne służyły rozrywce, były zabawne i zrozumiałe dla widza, miały prosty przekaz: przedstawiały aktualne problemy społeczne, czasem zawierały wątki romantyczne, niosły moralizatorskie przesłanie. W finale sztuki zwykle mamy uogólnienie, morał - bohaterowie dostają nauczkę lub przestrogę, którą podsumowuje tytułowe proverbium przytaczane na zakończenie. Ten dydaktyzm przysłów chętnie wykorzystywany był w literaturze dla dzieci i młodzieży, m.in. przez Paulinę Krakowową z Radziejowskich,

\footnotetext{
${ }^{16}$ W.L. Anczyc, Nie kładź palca między drzwi, „Józefa Ungra Kalendarz Warszawski Popularno-Naukowy Ilustrowany", R. 20: 1865, s. 17-19; E. Lubowski, Nie wszystko złoto, co się świeci, „Opiekun Domowy”, R. 1: 1865, nr 10, s. 74-77 i nr 12, s. 90-93 oraz Skapy dwa razy traci, „Opiekun Domowy", R. 2: 1866, nr 10, s. 74-76, nr 11, s. 83-84, nr 12, s. 91-94.

${ }^{17}$ Zob. J.K. Gregorowicz, Nie wszystko złoto, co się świeci. Komedia w 1 akcie, „Gazeta Codzienna" 1856, nr 3, s. 1-2. W czasopiśmie znalazły się tylko dwie sceny. Miał być ciąg dalszy, ale kontynuacja nie ukazała się.

${ }^{18}$ G. Puzynina, Trafita kosa na kamień. Krotofila $w$ dwóch odsłonach, (z rękopisów pośmiertnych ś.p. Gabrieli Puzyniny), „Kronika Rodzinna”, R. 3: 1869/1870, nr 7, s. 97-100.

${ }^{19}$ G. Puzynina, dz. cyt., s. 100.

${ }^{20}$ Tamże.
} 
założycielkę pensji dla dziewcząt, autorkę popularnych Wieczorów domowych (do 1894 roku pięciokrotnie wznawianych) ${ }^{21}$ oraz przez, piszących do popularnych w latach 80. i 90. czasopism o charakterze wychowawczo-edukacyjnym, szczególnie „Wieczorów Rodzinnych” i „Przyjaciela Dzieci”, Michalinę Zielińską-Grzymałę, Reginę Pniowerównę, Emilię Lejową, Marię Pomorską i Jana Kantego Gregorowicza. Bohaterami ich utworów najczęściej są dzieci i ucząca się młodzież, jak w komedii w jednej odsłonie Filozof czyli Nie wszystko złoto, co się świeci. Akcję tej historyjki Pomorska umieściła w wiejskim saloniku, gdzie do trzech sióstr przyjeżdża szesnastoletni kolega, przemądrzały Henio. Cała rzecz prowadzi do morału:

człowiek im rozumniejszy, tym przystępniejszy jest dla niższych umysłem od siebie. Taki nie będzie się sadził na górne dla efektu frazesa, a postara się rzecz wyłożyć najjaśniej i najzrozumialej. Bo mu idzie nie o popis, ale o pożytek dla słuchaczy [...] Nie wszystko złoto, co się świeci² ${ }^{22}$

po którym następuje jeszcze długa eksplikacja zaistniałego wydarzenia. Ciekawsze są komedyjki Zielińskiej-Grzymały, jak dość sprawna, umieszczona w scenerii żeńskiej szkoły wierszowana dwuaktówka Kto pod kim dołki kopie, czy pełna dydaktyzmu sztuka Bez pracy nie ma kołaczy ${ }^{23}$, niosąca przesłanie zarówno dla leniwych dzieci, jak dla nadopiekuńczych i pobłażliwych rodziców. Moralizatorskie obrazki dramatyczne Gregorowicza: Myszy tańcuja, jak kota nie czują ${ }^{24}$ oraz Trafita kosa na kamieńn ${ }^{25}$, były przeznaczone dla teatrzyków dziecięcych. Zawierają bardzo dokładne wskazówki sceniczne dla małych aktorów oraz bezpośrednie zwroty do publiczności (np. przeprosiny ,za zbytki”). Jedyną ciekawostką w tych utworach jest autoreklama - polecenie czytania „Zorzy” redagowanej przez Gregorowicza.

Przysłowia były wydawane $\mathrm{w}$ różnych zbiorach kierowanych do teatrów amatorskich (założonych m.in. w Kaliszu, Lublinie, Dąbrowie Górniczej i Bydgoszczy) oraz do teatrów domowych ${ }^{26}$. Możliwość wystawienia krótkich drama-

${ }^{21}$ P. Krakowowa, Lepiej mało a dobrze, niz wiele a licho. Przysłowie w 1 obrazie, w: Wieczory domowe. Zbiór zabawek, opisów i powiastek dla nauki i rozrywki dobrych dzieci, zebr. P. Kraków, Księgarnia Samuela Orgelbranda, Warszawa 1848, s. 183-212.

${ }_{22}$ M. Pomorska, Filozof czyli Nie wszystko złoto, co się świeci. Komedyjka w jednej odsłonie, „Wieczory Rodzinne”, R. 5: 1884, nr 42, s. 663-666 i nr 43, s. 682-684.

${ }^{23}$ M..... [M. Zielińska-Grzymała], Kto pod kim dołki kopie, sam w nie wpada. Przysłowie dramatyczne w 2 aktach, ,Wieczory Rodzinne”, R. 3: 1882, nr 24, s. 370-373 i nr 25, s. 394-396 oraz Nie wszystko złoto, co się świeci. Obrazek sceniczny w 2 aktach, tamże, nr 38, s. 598-604 i nr 39, s. $610-614$.

24 J.K. Gregorowicz, Myszy tańcuja, jak kota nie czują. Obrazek dramatyczny w jednej odsłonie, „Dodatek powieściowy do «Przyjaciela Dzieci»” 1872, nr 52, s. 629-631.

${ }^{25}$ Po raz pierwszy opublikowane w: Nasz plon. Ksiązka Pamiatkowa Pięćdziesięciolecia „Przyjaciela Dzieci”, Wydawnictwo „Przyjaciel Dzieci”, Warszawa 1912, s. 47-72.

${ }^{26}$ M.in. seria wydawnicza „Biblioteka Teatrów Amatorskich”, zainicjowana w 1883 we Lwowie przez Hermana Altenberga. 
tów w domu była jedną z przyczyn popularności tej drobnej formy scenicznej. W liście-dedykacji poprzedzającym przysłowie Leona Kaplińskiego Ufność bez granic (1871) autor przytacza słowa hrabiny Walerii Mycielskiej: „w naszej literaturze jest za mało lekkich i krótkich scenicznych utworów, które można przedstawić na zaimprowizowanym domowym teatrze, dla skrócenia zimowego wieczoru” "27, zastanawiając się jednocześnie, czy „tę błahostkę można nazwać przysłowiem po polsku" ${ }^{28}$. Utwór Kaplińskiego nie jest udany, opiera się głównie na rozmowie zazdrosnego męża z żoną. Dialog jest bardzo schematyczny i statyczny, częściej stanowi wymianę przydługich, nudnych tyrad niż rozmowę małżonków. Autor próbował przemycić pewne wartości - dla głównego bohatera, Romana, miłośnika czasopisma „Revue des Deux Mondes”29, orientacja w problemach współczesnego świata, czytanie i poznawanie literatury zachodniej jest ważniejsze niż „bywanie na salonach”, a jego żona Anna wygłasza feministyczne uwagi. To wszystko jednak gdzieś umyka w błahej, przewidywalnej intrydze, która zamyka się w słowach wypowiedzianych przez Annę w ostatniej scenie: „Wolę, byś mnie kochał bez ufności niż ufał nie kochając”30.

Zdecydowanie inne jest jednoaktowe przysłowie dramatyczne Aleksandra Fredry Z jakim się wdajesz, takim się stajesz. Data powstania tej krótkiej, liczącej dziesięć scen komedii nie jest znana. Według Stanisława Pigonia Fredro napisał ją około roku 1865; Eugeniusz Kucharski przypuszczał, że powstała pomiędzy 1857 a $1862^{31}$. Począwszy od warszawskiej premiery w 1877 roku grana była w teatrach Lwowa i Krakowa. To jeden z późnych, napisanych po długim milczeniu Fredry, utworów. Jest tu charakterystyczne odejście od idyllicznego dworku szlacheckiego, w którym autor umieszczał akcje swoich wcześniejszych dramatów. Rzecz dzieje się w małym miasteczku i dotyczy dwóch spokrewnionych starszych małżeństw. Źródłem humoru są m.in. znaczące nazwiska bohaterów (oprócz naiwnych, życzliwych braci Dobrostów mamy bałamutnika Fikalskiego i podstępnego, złośliwego sąsiada, Mateusza Zgagę), elementy farsy (zamknięcie Mateusza w szafie), komizm słowny (wywód Barbary o wierności małżeńskiej w Paryżu), porównania i frazeologizmy uwydatniające cechy bohaterów: „nie patrzcie jak sowy” (w. 261), „w potrzebie stanę się lwem [...] cętkowanym tygrysem [...] rozjuszonym niedźwiedziem” (w. 269-74), „mądra to żmija” (w. 285), „to

${ }^{27}$ L. Kapliński, Ufność bez granic. Przysłowie dramatyczne w jednym akcie, Drukarnia Leona Paszkowskiego, Kraków 1872, s. 3.

${ }^{28}$ Tamże.

29 „Revue des Deux Mondes” - jedno z najstarszych, wydawanych od roku 1829 do dzisiaj, czasopism Europy. Pismo miało stanowić pomost kulturalny, polityczny i ekonomiczny pomiędzy dwoma światami - Starym (Francją) a Nowym (Stanami Zjednoczonymi).

${ }^{30}$ L. Kapliński, dz. cyt., s. 23.

${ }^{31}$ E. Kucharski, Chronologia komedyj i niektórych pomniejszych utworów Al. Fredry, Polska Akademia Umiejętności, Kraków 1923, s. 53-55. 
szczwany lis" (w. 290) ${ }^{32}$. Dynamiczna akcja tej komedii intrygi, z krótkimi, obfitującymi w wykrzykniki dialogami, rozgrywa się w jednym miejscu - w dużym pokoju - i jest ilustracją tytułowego przysłowia. Komedia, jak wszystkie sztuki Fredry, zawiera szczególnie dokładne wskazówki opisujące zachowanie postaci, choć sam autor zarządzil, żeby utwory napisane pod koniec życia najpierw rozpowszechniono drukiem. Kiedy Rada Przyjaciół pod kierunkiem syna pisarza, Jana Aleksandra, oceniała wydobytą z szuflady spuściznę, początkowo przysłowie $Z$ jakim się wdajesz, takim się stajesz przydzielono do grupy słabszych dramatów, ale później zmieniono kwalifikację ${ }^{33}$. Ta sztuka ma swoje istotne miejsce w twórczości wybitnego komediopisarza. Kazimierz Wyka widział ją jako jeden $\mathrm{z}$ istotnych elementów przygotowania do Zapisków starucha, mając na myśli:

to przygotowanie, jakie w tekście komedii Fredrowskich stwarza jego [Fredry] umiejętność lakonicznego i dowcipnego uogólnienia danej sytuacji, umiejętność powodująca, że w tekstach tych pojawia się wielokrotnie zjawisko, które można by nazwać - aforyzm w ruchu. Aforyzm w działaniu scenicznym, sentencja na gorąco wydobywana z towarzyszących jej okoliczności ${ }^{34}$.

W rozmowie zafrasowanej Barbary i Marty pada przysłowie: „W starych piecach diabeł pali" (w. 52-53), a Zgaga, zły charakter tego dramatu, przysłowiem: „Strzeżonego Pan Bóg strzeże” (w. 202), biblijną sentencją: „Szukajcie a znajdziecie” (w. 203, 209-210) oraz frazeologizmami: „Wszystkie na jedno kopyto” (w. 209), „Nie z jednego pieca chleb jadłem” (w. 76-77), uzasadnia swoje bezpodstawne oskarżenia. Michał Dobrost, kiedy chce się uwolnić od znajomości z sąsiadem, powie: „Co było, a nie jest, to nie pisz w rejestr” (w. 480), a jego brat, chcąc załagodzić sprawę, wykorzysta przysłowie: „Będzie wilk syty i owca cała" (w. 485). Kiedy, dzięki podstępowi mądrych żon i sprytnej służącej, miłość małżeńska i wartości rodzinne zwyciężają, na zakończenie Barbara konkluduje: „żyliście ze złym człowiekiem i złemu człowiekowi daliście się obałamucić” (w. 525-526), ,,pamiętajcie dawne przysłowie; z jakim się wdajesz, takim się stajesz" (w. 528-529).

Sytuacja typu: „sprawdzam” jest charakterystyczna także dla pisanych trzynastozgłoskowcem przysłów dramatycznych Jana Chęcińskiego. Chęciński - pisarz, ale przede wszystkim człowiek teatru, aktor i reżyser, znany z libretta

\footnotetext{
32 Wszystkie fragmenty przysłowia dramatycznego Fredry przytoczone w artykule pochodzą z wydania: A. Fredro, Zjakim się wdajesz, takim się stajesz, w: tegoż, Pisma wszystkie, t. 9: Komedie, Seria druga, oprac. S. Pigoń, Państwowy Instytut Wydawniczy, Warszawa 1958, s. 249-281.

${ }^{33}$ H. Barycz, Sąd nad twórczościq sceniczna Aleksandra Fredry, „Pamiętnik Literacki” 1951, z. 1, s. 251-257.

${ }^{34}$ K. Wyka, Wstep do: A. Fredro, Pisma wszystkie, t. 7: Komedie, Seria druga, oprac. S. Pigoń, Państwowy Instytut Wydawniczy, Warszawa 1958, s. 58.
} 
operowego Straszny dwór - związany był głównie ze sceną warszawską i właśnie w Warszawie przysłowia sceniczne jego autorstwa miały swoje teatralne premiery oraz pierwsze edycje. Najciekawszym utworem jest komedia Przed obiadem i po obiedzie, wydana i wystawiona w 1862 roku. W gorzki, ironiczny sposób przedstawia istotne społeczne problemy: biedy, bezrobocia, niskiej płacy, ale finał ma szczęśliwy. Głównym i zarazem negatywnym bohaterem jest zamożny Walenty, narzekający na kłopoty z otrzymanym spadkiem. Akcja toczy się w saloniku, wszystko obraca się wokół obiadu, na który czeka głodny i zniecierpliwiony gospodarz. Czekając, przyjmuje gości: Stefana, kolegę ze studiów, mającego poważne kłopoty z utrzymaniem rodziny, Radcę oraz Ignacego, który przyszedł prosić o pracę dla syna hulaki. Widać kontrast pomiędzy słowami Walentego a jego czynami. Całość jest tak poprowadzona, że nie jesteśmy pewni, czy Walenty jest dobroduszny, czy może naiwny. W trakcie rozmów z gośćmi powoli obnażany jest jego prawdziwy charakter - chciwość i obłuda, podkreślona m.in. słowami: „A są ludzie, u których powstaje myśl zdrożna, / Że w dziewiętnastym wieku z głodu umrzeć można!"35. Kontrast wyostrza postać pukającego do drzwi w czasie biesiady przy suto zastawionym stole głodnego nędzarza, który od Walentego dostaje... herbatę. Sztuka jest ilustracją przysłowia „syty głodnemu nie wierzy”, wypowiadanego na koniec przez rozgoryczonego Stefana.

Dwa przysłowia dramatyczne Chęcińskiego cieszyły się dużą popularnością, wystawiane były przez wiele lat nie tylko w Warszawie, ale też na deskach teatrów lwowskiego i krakowskiego. Są to: Ciekawość pierwszy stopień do piekta, sztuka napisana przed 1863 rokiem (premiera i pierwsza edycja w Warszawie rok później), oraz przysłowie Cicha woda brzegi rwie, wystawione i opublikowane w 1867 roku. To typowe sceniczne ilustracje porzekadeł zawartych w tytule. Akcja obu utworów rozgrywa się w mieszczańskich salonach, adwokata i profesora, w Warszawie. Jest więc nowy bohater dramatów z tego okresu - mieszczanin, inteligent. Pierwsza sztuka to komedia małżeńska, o spokojnym tempie, oparta na intrydze zazdrosnej, świętoszkowatej Brygidy, która zasiewa niepewność w małżeństwie brata. Tytułowe przysłowie pojawia się już w drugiej scenie i nawet zabawnie brzmi w ustach dewotki, ale w dalszej części dramatu nic nie zaskakuje, wszystko - i schematyczne zachowania bohaterów, i finał - jest przewidywalne, a przydługie partie monologowe wydają się dzisiaj nużące. Druga z komedii może się obronić na współczesnej scenie. Pisana była z myślą o znanych aktorach: Wincentym Rapackim, Marcelinie Ekerowej, Józefie Bendzie, Bolesławie Ładnowskim i Helenie Modrzejewskiej, a w lwowskim teatrze wystawiana była jeszcze przez całą dekadę od dnia premiery. Pojawia się w niej wątek „być czy

35 J. Chęciński, Przed obiadem i po obiedzie. Przysłowie dramatyczne, w jednym akcie wierszem, Gebethner i Wolff, Warszawa 1862, s. 27. 
mieć”. Są wyraźnie zarysowane postaci głównych bohaterów: potulny, spokojny profesor Roch, dla którego książki są całym światem, oraz jego przeciwieństwo ambitna żona Dorota, która już w pierwszej scenie tak mówi do męża:

Co mi stąd, że tam mądrość jakiegoś Wirgila

Swoją stęchłą bibułą mądrość ci posila,

Gdy przy najsytszym duchu, o zwyczajnej porze

Żołądek bez obiadu obejść się nie może;

Gdy lat tyle wertując mądrych śmieci pudło

Choć utuczyłeś ducha, ciało tak ci schudło,

Że ani pojąć zdoła mój rozum niewieści,

Jak się twój duch spasły w takim śledziu mieści! $!^{36}$

Cała akcja dramatu skupiona jest wokół planowanego małżeństwa córki czy ma wyjść za głupiego, acz majętnego Gerwazego, czego życzyłaby sobie matka, czy za młodego uczonego Wiktora, w którym przyszłego zięcia widziałby ojciec. Wypowiedzi Doroty są ostre, pełne emocji i wykrzykników, z dużą liczbą powtórzeń, którymi zaklina rzeczywistość. Jak mantra przez cały utwór przewija się zdanie celnie opisujące postać Gerwazego: ,jeszcze młody, a już ma dwa domy". Gwałtowne, ironiczne dialogi dynamizują całą akcję, szczególnie pod koniec, kiedy Roch odkrywa intrygi żony i role się odwracają, a wszystko nabiera tempa.

Kolejny utwór Chęcińskiego, $W$ niełasce, wystawiony w Warszawie i wydany w roku 1868, jest sceniczną ilustracją przysłowia pojawiającego się w zakończeniu: „Gdzie złe przypadki, przyjaciel rzadki”. Rzecz ma miejsce w pokoju bawialnym dyrektora biura, który organizuje przyjęcie zaręczynowe dla swojej córki Ludwiki. Intryga jest bardziej skomplikowana niż w poprzednich utworach - uknuta przez ojca chrzestnego Ludwiki, Adolfa, poddającego próbie zarówno ufność głównego bohatera, wystawionego na knowania oraz plotki jego pracowników, jak uczciwość i uczucia narzeczonego Ludwiki, Władysława. Sztuka jest dynamiczna, ma szybkie tempo, przewija się dużo postaci drugoplanowych (inaczej niż w większości przysłów scenicznych, w których zwykle dialog prowadzą dwie lub trzy osoby), bohaterowie są bardzo charakterystyczni, a wypowiedzi obfitują w emocjonalne wyrażenia, wykrzykniki i pytania retoryczne.

W tym samym roku, co Cicha wode..., swoje przysłowie wierszem opublikował Ksawery Godebski. Akcja utworu Kto pod kim dołki kopie, sam w nie wpada została umieszczona na wsi, gdzie dwie pary młodych ludzi wzajemnie poddają

${ }^{36}$ J. Chęciński, Cicha woda brzegi rwie. Przysłowie dramatyczne w jednym akcie wierszem, Księgarnia Jana Konstantego Żupańskiego, Poznań 1868, s. 11. 
próbie swoje uczucia. Intrygą i nastrojem przypomina to nieco Śluby panieńskie, choć oczywiście temu urokliwemu drobiazgowi dramatycznemu z nieco nieporadnymi rymami, daleko do Fredrowskiej komedii miłości. To samo przysłowie wykorzystał śląski twórca Piotr Kołodziej, tytułując tak trzyaktowy obraz ludowy napisany do muzyki Adama Wrońskiego: Poczciwy mlynarz czyli Kto pod kim dotki kopie, sam w nie wpada (spektakle na podstawie tej sztuki grano w latach 90. w górnośląskich teatrach amatorskich).

Również na wsi odbywa się rozmowa bohaterów przysłowia dramatycznego Kosa i kamień Józefa Ignacego Kraszewskiego: Izy, panny o ciętym dowcipie, walczącej z konwenansami, i Roderyka, z którym chce ją wyswatać zrzędliwa ciotka. Ten pogodny romans został opublikowany w „Dzienniku Poznańskim” w 1873 roku. Sztuka miała dobre recenzje ${ }^{37}$, ale dzisiaj nuży słaba intryga oraz dialogi gęsto przeplatane aforyzmami i francuskimi makaronizmami, z dużą liczbą monologów à part. Nie ratuje utworu nawet postać umyślnego służącego Kalasantego, powtarzającego ciągle słowa: „dowiedziona rzecz”, próbującego pomóc młodym wybrnąc $\mathrm{z}$ sytuacji, w którą się zapędzili. Trafiają się w dramacie błyskotliwe riposty, jest też kilka ciekawych, socjologicznych spostrzeżeń - oprócz narzekania starszych na emancypację, postęp, tempo życia i zmianę obyczajów można znaleźć rozważania o emigracji młodych ludzi. Roderyk mówi m.in.: „rozumiem, iż można by w pewnych danych okolicznościach za kraj ten umrzeć - ale w nim żyć - to prawie niepodobieństwo [...] Kocham go, ale go nie lubię" "38. Interesujący jest fragment o masowości literatury, kiedyś elitarnej, teraz dostosowanej do odbiorcy i zróżnicowanej: „Bo też wielu dziś czyta. Muszą być literatury na wszystkie głowy. - Dawniej czytywała jedna klasa tylko, wybrana i wtajemniczona, a dziś wszyscy aż do lokajów i garderobiany"39. Sztuka ta w XIX wieku wystawiana była sporadycznie, za to współcześnie sięgają po nią teatry szkolne i amatorskie. Kraszewski jest także autorem przypowiastki w trzech aktach Łatwiej popsuć niż naprawićto, w której wieś ukazana jest jako Arkadia, a główny bohater odzyskuje tam siły i uczy się dystansu wobec zachłannego, brutalnego miejskiego życia. Komedia ta jest rozwlekłą, przetykaną łacińskimi sentencjami, historią bankruta-hulaki, który zaczyna rozumieć swoje błędy i, uzyskując przebaczenie, przekonuje się, kto jest prawdziwym przyjacielem. Tytułowe przysłowie pojawia się w zakończeniu sztuki. Dużo bardziej

\footnotetext{
${ }^{37}$ Zob. m.in.: H. Sienkiewicz, Teatr. „,Kosa i kamień, przystowie dramatyczne” J.I. Kraszewskiego, „Okno na pierwszym piętrze”, dram. w 1 akcie” J. Korzeniowskiego, w: „Niwa”, 1875, t. VII, zob. http://www.sienkiewicz.ovh.org/16/040.html [dostęp:10.11.2014].

38 J.I. Kraszewski, Kosa i kamień. Przysłowie dramatyczne, Księgarnia Jana Konstantego Żupańskiego, Poznań 1873, s. 16.

${ }^{39}$ Tamże, s. 30.

${ }^{40}$ J.I. Kraszewski, Łatwiej popsuć niż naprawić. Przypowiastka w trzech aktach, w: tegoż, Dwie komedyjki, Nakład i Druk Józefa Zawadzkiego, Wilno 1856, s. 145-245.
} 
udana jest ironiczna powieść Kraszewskiego nawiązująca do popularnego porzekadła $W$ starym piecu - o podstarzałym urzędniku Pampowskim, obracającym się w mieszczańsko-szlacheckim środowisku Warszawy lat 70.

To samo przysłowie wykorzystali: Roman Nowina ${ }^{41}$ w jednoaktówce wierszem $W$ starym piecu diabet pali (1879) oraz Zbigniew Wołodyjowski ${ }^{42} \mathrm{~W}$ „,komedyjce w 1 akcie", wydanej pod tymże tytułem razem z Monologiem zakochanej Wincentego Rapackiego w 1894 roku.

Ostatnie trzydziestolecie XIX wieku to okres, w którym przysłów scenicznych wystawia się i publikuje dużo, zarówno tłumaczonych, np. bluetkę Giuseppe Giacosy Nie łów ryb przed niewodem w przekładzie Jana Tańskiego, jak i rodzimych twórców, m.in. Henryka Łączyńskiego Za pania matka idzie pacierz gładko (wydano je we Lwowie w 1878 roku) oraz Władysława Koziebrodzkiego Celina czyli Miłe złego początki, które zwyciężyło w krakowskim konkursie w 1873 roku. Akcja ostatniej komedii rozgrywa się w eleganckim mieszczańskim saloniku. To bardzo moralizatorska sztuka, w której sprytna intryga Karoliny, krewnej głównych bohaterów - Celiny i Włodzimierza, pozwala uchronić ich małżeństwo przed romansem Celiny z przyjacielem męża, Edwinem. Dramat zwraca uwagę na wartości rodzinne i wzajemną małżeńską troskę.

Obecna na deskach teatrów Galicji w latach 70. i 80. farsa „Gogo”. Nie mów hop, aż przeskoczysz hrabiego Wincentego Bobrowskiego ${ }^{43}$ (wystawiana od 1868 roku, a wydana we Lwowie w 1896 roku) ma zadziwiająco zbieżny główny wątek z podobnie zatytułowanym przysłowiem Zofii Lasockiej z Mikorskich - upokorzenie amanta podrywającego mężatkę. W sztuce Bobrowskiego małżeństwo Julii i Karola daje nauczkę zaproszonemu do ich domu Adolfowi, a pełen zamierzonych absurdów dialog obnaża zamiary wciągniętego w małżeńską grę nieszczęśnika. Wierszowana jednoaktówka Lasockiej, po spektaklu w 1889 roku w warszawskim Teatrze Rozmaitości, została chłodno przyjęta przez krytykę:

napisała ją «kobieta wyłącznie ze świata salonowego», ale że fakt ten nie thumaczy słabiutkiego poziomu sztuki. Pomysł upokorzenia lowelasa, szukającego łatwego romansu z mężatką znalazł nawet uznanie, ale osądzono, że «odrobienie pomysłu szwankowało» ${ }^{44}$.

\footnotetext{
${ }^{41}$ Pod tym pseudonimem pisał Roman Bronisław Przyrembel.

42 Pseudonim Władysława Dunin-Wąsowicza.

${ }^{43}$ Bobrowski był też autorem przysłowia dramatycznego w 1 akcie Nauka nie idzie w las, wystawianego we Lwowie (1873) i w Krakowie (1874), ale tekst się nie zachował.

${ }^{44}$ K.B. [J. Kaden-Bandrowski?], Teatry warszawskie przed pót i ćwierćwiekiem, „Teatr. Wydawnictwo Towarzystwa Krzewienia Kultury Teatralnej w Polsce", R. 6: 1938/1939, nr 9-10 (57-58), s. 14.
} 
Pod koniec wieku przysłowia nadal publikowane są w czasopismach i kalendarzach, m.in. nudnawy, niezbyt udany, napisany pod pseudonimem utwór Celiny Gładkowskiej z Wołoskich Kto się czubi ten się lubi ${ }^{45}$, pretensjonalna i przeładowana przysłowiami dwuaktówka Zygmunta Rupperta (nazwana „śmiesznostką do grania w teatrach amatorskich") Miłe zlego poczatki - lecz koniec żałosny ${ }^{46}$ oraz nieco ambitniejsze utwory Ireny Mrozowickiej, bardziej literackie niż teatralne: Mowa jest srebrem a milczenie złotem (to raczej krótka, zabawna, rozbudowana anegdota aniżeli przysłowie sceniczne, z podziałem na role, ale bez podziału na sceny i bez didaskaliów), Złapał żolnierz Tatarzyna, a Tatarzyn za teb trzyma (opowieść o mądrej żonie, mężu raptusie i naprzykrzających się teściach) oraz Gdzie diabet nie może, tam babę pośle ${ }^{47}$ (historia protekcji w sprawie przyjęcia do pracy opowiedziana w trzech krótkich scenach).

Przełom wieku XIX i XX to już czas niemalże masowej produkcji jednoaktówek. Do jej zwiększenia przyczyniła się komercjalizacja rynku literackiego i teatralnego oraz trwające od kilkudziesięciu lat przemiany w zawodzie aktora (łączenie go z pisarstwem i reżyserowaniem), których odzwierciedleniem były m.in. sztuki metateatralne (np. monodramaty, tytułem odwołujące się do porzekadła: „natura ciągnie wilka do lasu” ${ }^{48}$, o poszukiwaniu harmonii przez aktorów, którzy próbowali odejść z zawodu). Duża konkurencja w zawodzie aktorskim, powszechne konkursy dramatyczne oraz wymogi rynku, m.in. sposób wynagradzania aktorów za udział w każdym spektaklu (tzw. występowe) - wszystko to miało wpływ na częstotliwość grania jednoaktówek i na swoistą ich plagę ${ }^{49}$. Były to często jednorazowe przedstawienia grane przy okazji świąt bądź festynów, pisane przez ich aktorów, którzy sami przygotowywali te spektakle. Takimi twórcami byli m.in.: Edward Lubowski, Aleksander Ładnowski (autor m.in. komedii w 1 akcie Trafiła kosa na kamień) ${ }^{50}$, Józef Dłuski ${ }^{51}$ (autor przeróbki po-

45 J. Morosz [pseud. C. Gładkowskiej], Kto się czubi ten się lubi, „Bluszcz”, R. 26: 1890, nr 10, s. $76-77, \mathrm{nr} 11$, s. $84-85$, nr 12, s. 92-93.

${ }^{46}$ Mikado [Z. Ruppert], Miłe złego początki - lecz koniec żałosny. Historia stara jak świat ujęta w dwa krótkie akty, ,Albumowy Kalendarz Polski Satyryczny”, R. 2: 1895, s. 32-33.

${ }^{47}$ Irena M. Nagoda [I. Mrozowicka], Mowa jest srebrem a milczenie złotem, „Echo Muzyczne, Teatralne i Artystyczne", R. 11: 1894, nr 26, s. 311-12; Złapał żotnierz Tatarzyna a Tatarzyna za teb trzyma, tamże, R. 12: 1895, nr 30, s. 350-351; Gdzie diabet nie może tam babę pośle, tamże, R. 12: 1895 , nr 29, s. 338-339.

${ }^{48}$ Natura wilka wyciaga z lasu Władysława Syrokomli - wystawiony w Teatrze Starym w Krakowie (1865) i Natura wilka ciagnie do lasu Józefa Grajnerta - monodram odegrany przez Aleksandrę Rakiewiczową na dochód przytuliska w czasie przedstawienia żywych obrazów, które odbyło się na scenie Teatru Wielkiego (1875).

${ }^{49}$ Zob. Z. Szweykowski, Krytyka teatralna $w$ dobie pozytywizmu wobec aktora i reżysera, „Pamiętnik Teatralny” 1953, t. 2, nr 1 (5), s. 133-136.

${ }^{50}$ Wystawiona była w Bielsku (1863) i w Krakowie (1865).

${ }^{51}$ Pisał pod pseudonimem J. Sieprawiak albo Sieprawa. 
wiastki ludowej Nie miała baba kłopotu ${ }^{52}$, wystawionej w teatrze ogródkowym przy warszawskim „Wodewilu”).

Przeglądając przysłowia sceniczne powstałe w XIX wieku, można zauważyć ewolucję tego gatunku. Na gruncie francuskim powstały przeróżne odmiany, m.in. opera proverbe, proverbe parodie. Synkretyzm gatunkowy można dostrzec również w krajowej dramaturgii - przysłowia krzyżują się z komedią obyczajową i romantyczną, komedią pomyłek i charakterów, tragikomedią, krotochwilą, farsą, obrazkiem. W polskiej twórczości dominują bluetki, ale zdarzają się też dłuższe utwory dramatyczne, jak obraz ludowy Kołodzieja czy krotochwila w trzech aktach Na złodzieju czapka gore Adolfa Abrahamowicza i Apolla Choromańskiego (wystawiona w teatrze lwowskim w 1881 roku). Przesuwa się punkt ciężkości: z żartobliwych, czasem dydaktycznych, luźnych scenek ilustrujących przysłowie na rozbudowane utwory sceniczne, w których pojawia się problematyka obyczajowa i społeczna, choć zawsze w zakończeniu jest morał pod postacią sentencji, przysłowia. Pojawia się też nowy bohater: zamiast salonowego bawidamka i szlachcica - mieszczański inteligent. Przysłowie dramatyczne jako gatunek przetrwało, choć sama jego nazwa, będąca dosłownym tłumaczeniem terminu 'proverbe dramatique', jest niezbyt udana. Zdecydowanie odpowiedniejszy, oddający charakter i pochodzenie tej drobnej formy, jest przekład Janiny Błońskiej: 'przysłowie sceniczne ${ }^{53}$, jednakże w dziewiętnastowiecznych edycjach określenia 'przysłowie dramatyczne' i 'przysłowie udramatyzowane' funkcjonowały. Gatunek miał swoje realizacje $\mathrm{w}$ dwudziestoleciu międzywojennym. Z salonowej zabawy przerodził się w utwór literacki oparty na rozmowie. „Mówienie jest w nim ważniejsze od działania, organizuje tekst" ${ }^{\prime 4}$, a sama forma wpisuje się w nurt dramatu konwersacyjnego. Gatunek został przywrócony do życia w latach 80 . ubiegłego wieku przez kino Érica Rohmera. W filmach tego reżysera, nawiązujących do tradycji literatury oświeceniowej, również najważniejszy jest dialog ${ }^{55}$.

\section{Bibliografia}

Anczyc Władysław Ludwik, Nie kładź palca między drzwi, „Józefa Ungra Kalendarz Warszawski Popularno-Naukowy Ilustrowany”, R. 20: 1865, s. 17-19.

Barycz Henryk, Sąd nad twórczością sceniczną Aleksandra Fredry, „Pamiętnik Literacki” 1951, t. 42 , z. 1, s. 251-257.

52 Zob. recenzje przedstawienia w: „Echo Muzyczne, Teatralne i Artystyczne”, R. 5: 1888, $\mathrm{nr}$ 254, s. 365. Pod identycznym tytułem: Nie miała baba kłopotu, kupiła sobie... męża w 1911 roku w Chicago wydana została króciutka powiastka ludowa prozą autorstwa Józefa Morosza.

${ }^{53}$ J. Błońska, L'Entr'Acte, http://www.wsp.krakow.pl/konspekt/18/blonska.html [dostęp: 10.11.2014].

${ }^{54}$ Zob. D. Jarząbek, Fenomen rozmowy w dramacie, „Przestrzenie Teorii” 2006, nr 6, s. 268.

${ }^{55}$ Filmowe cykle Érica Rohmera: Sześć opowieści moralnych, Komedie i przysłowia, Opowieści czterech pór roku. 
Bibliografia dramatu polskiego 1765-1964, t. 1-2: Ludwik Simon, Bibliografia dramatu polskiego 1765-1939, oprac. i red. E. Heise i T. Sivert, Państwowy Instytut Wydawniczy, Warszawa 1972.

Błońska Janina, L'Entr'Acte, http://www.wsp.krakow.pl/konspekt/18/blonska.html [dostęp: 10.11.2014].

Bobrowski Wincenty, „Gogo”. (Nie mów hop, aż przeskoczysz), nakł. H. Altenberga, druk. W.A. Szyjkowskiego, Lwów 1896.

Chęciński Jan, Cicha woda brzegi rwie. Przystowie dramatyczne w jednym akcie wierszem, nakł. Księgarni Jana Konstantego Żupańskiego, Poznań 1868.

Chęciński Jan, Przed obiadem i po obiedzie. Przystowie dramatyczne, w jednym akcie wierszem, Gebethner i Wolff, Warszawa 1862.

Dubois Jean Baptiste, (Ukarany zazdrośnik). Trafiła kosa na kamień. Komedia w 1 akcie z francuskiego tłomaczona przez I. Majeranowskiego [egzemplarz teatralny], przeł. Konstanty Majeranowski, 1846, http://www.europeana.eu/portal/record/09404/id_oai_www_sbc_org_ pl_24972.html [dostęp: 15.11.2014].

Estreicher Karol, Bibliografia polska XIX stulecia, wyd. 2 nowe, t. 4: D-Dramat polski, Państwowe Wydawnictwo Naukowe, Kraków 1966.

Fredro Aleksander, Zjakim się wdajesz, takim się stajesz, w: tegoż, Pisma wszystkie, t. 9: Komedie, Seria druga, oprac. S. Pigoń, Państwowy Instytut Wydawniczy, Warszawa 1958, s. 249-281.

Gładkowska Cecylia [pseud. J. Morosz], Kto się czubi ten się lubi, „Bluszcz”, R. 26: 1890, nr 10, s. 76-77, nr 11, s. 84-85; nr 12, s. 92-93.

Gładkowska Cecylia [pseud. Julian Morosz], Nie miała baba kłopotu, kupiła sobie... męża! Powiastka ludowa, W. Dyniewicz, Chicago 1911.

Grajnert Józef, Natura wilka ciagnie do lasu. Monodramat wierszem, „Ognisko domowe” 1875, t. 1, nr 29, s. 232-233; nr 30, s. 240-241.

Gregorowicz Jan Kanty, Myszy tańcuja, jak kota nie czuja. Obrazek dramatyczny w jednej odsłonie, „Dodatek powieściowy do «Przyjaciela Dzieci»” 1872, nr 52, s. 629-631.

Gregorowicz Jan Kanty, Nie wszystko złoto, co sięświeci. Komedia w 1 akcie, „Gazeta Codzienna” 1856, nr 3, s. 1-2.

Gregorowicz Jan Kanty, Trafita kosa na kamień, w: Nasz plon. Książka Pamiątkowa Pięćdziesięciolecia „Przyjaciela Dzieci”, Wydawnictwo „Przyjaciel Dzieci”, Warszawa 1912, s. 47-72.

Inglot Mieczysław, Komedie Aleksandra Fredry. Literatura i teatr, Ossolineum, Wrocław 1987.

Jarząbek Dorota, Fenomen rozmowy w dramacie, „Przestrzenie Teorii” 2006, nr 6, s. 267-273.

K.B. [Kaden-Bandrowski Juliusz ?], Teatry warszawskie przed pół i ćwierćwiekiem, „Teatr. Wydawnictwo Towarzystwa Krzewienia Kultury Teatralnej w Polsce”, R. 6: 1938/1939, nr 9-10 (57-58), s. 14-16.

Kapliński Leon, Ufność bez granic. Przystowie dramatyczne w jednym akcie, Drukarnia Leona Paszkowskiego, Kraków 1872.

Kondratowicz Ludwik [pseud. Władysław Syrokomla], Natura wilka wyciaga z lasu. Monodramat wierszem (z dodaniem garstki nowych poezji) Władysława Syrokomli, R. Rafałowicz, Wilno 1860.

Krakowowa Paulina, Lepiej mało a dobrze, niż wiele a licho. Przysłowie w 1 obrazie, w: Wieczory domowe. Zbiór zabawek, opisów i powiastek dla nauki i rozrywki dobrych dzieci, zebr. P. Kraków, Księgarnia Samuela Orgelbranda, Warszawa 1848, s. 183-212.

Kraszewski Józef Ignacy, Kosa i kamień. Przysłowie dramatyczne, Księgarnia Jana Konstantego Żupańskiego, Poznań 1873. 
Kraszewski Józef Ignacy, Łatwiej popsuć niż naprawić. Przypowiastka w trzech aktach, w: tegoż, Dwie komedyjki, Nakład i Druk Józefa Zawadzkiego, Wilno 1856, s. 145-245.

Kucharski Eugeniusz, Chronologia komedyj i niektórych pomniejszych utworów Al. Fredry, Polska Akademia Umiejętności, Kraków 1923.

LeBoeuf Ava Carolyn, The Proverbe dramatique before Carmontelle, The University of Texas at Austin 2010, http://repositories.lib.utexas.edu/bitstream/handle/2152/ETDUT-2010-05-1025/LEBOEUF-DISSERTATION.pdf [dostęp: 10.11.2014].

Lubowski Edward, Nie wszystko złoto, co się świeci, „Opiekun Domowy”, R. 1: 1865, nr 10, s. 74-77 i nr 12, s. 90-93.

Lubowski Edward, Skapy dwa razy traci, „Opiekun Domowy”, R. 2: 1866, nr 10, s. 74-76, nr 11, s. $83-84$ i nr 12, s. 91-94.

Maintenon Françoise d'Aubigné, Proverbes inédits de madame la marquise de Maintenon, publiés par M. de Monmerqué, J.-J. Blaise, Paris 1829.

Marszałek Agnieszka, Repertuar teatru polskiego we Lwowie 1864-1875, Towarzystwo Naukowe Societas Vistulana, Kraków 2003.

Marszałek Agnieszka, Repertuar teatru polskiego we Lwowie 1875-1881, Wydawnictwo Universitas, Kraków 1992.

Mrozowicka Irena [pseud. Irena M. (Nagoda)], Gdzie diabet nie może tam babę pośle, „Echo Muzyczne, Teatralne i Artystyczne", R. 12: 1895, nr 29, s. 338-339.

Mrozowicka Irena [pseud. Irena M. (Nagoda)], Złapał żolnierz Tatarzyna a Tatarzyna za łeb trzy$m a$, „Echo Muzyczne, Teatralne i Artystyczne”, R. 12: 1895, nr 30, s. 350-351.

Mrozowicka Irena [pseud. Nagoda], Mowa jest srebrem a milczenie złotem, „Echo Muzyczne, Teatralne i Artystyczne", R. 11: 1894, nr 26, s. 311-312.

Murat de Castelnau Henriete-Julie, Comédies en proverbes de Madame D***, w: tejże, Voyage de campagne, t. 2, Paris 1734, s. 73-286.

Nicoll Andrea, Dzieje dramatu od Ajschylosa do Anouilha, t. 1, thum. Henryk Krzeczkowski, Wacław Niepokólczycki, Jerzy Nowacki, wyd. 3, Państwowy Instytut Wydawniczy, Warszawa 1983.

Pepłowski Stanisław, Teatr polski we Lwowie (1780-1881), Księgarnia Gubrynowicza i Schmidta z Drukarni „Dziennika Polskiego”, Lwów 1889.

Pomorska Maria, Filozof, czyli nie wszystko złoto, co się świeci. Komedyjka w jednej odsłonie, „Wieczory Rodzinne”, R. 5: 1884, nr 42, s. 663-666; nr 43, s. 682-684.

Potocki Jan, Ślepiec, tłum. Piotr Szymonowski, „Dialog” 1993, t. 38, nr 8, s. 14-20.

Puzynina Gabriela, Trafita kosa na kamień. Krotofila w dwóch odsłonach (z rękopisów pośmiertnych ś.p. Gabrieli Puzyniny), „Kronika Rodzinna”, R. 3: 1869/1870, nr 7, s. 97-100.

Repertuar Starego Teatru (Teatru Krakowskiego) od 1781 do czerwca 2011 roku. Sztuki dramatyczne i operowe zespotu polskiego z lat 1781-1893, http://www.cyfrowemuzeum.stary.pl/ repertuar_od_1781 [dostęp: 15.11.2014].

Robert, dramatyczne przysłowie. W jednym akcie, w: Teatr dla dzieci czyli Zbiór sztuk wspótczesnych, przekł. z fr. Paweł Eustachy Leśniewski, Drukarnia Piotra Baryckiego, Warszawa 1838 .

Ruppert Zygmunt [pseud. Mikado], Miłe złego początki - lecz koniec żałosny. Historya stara jak świat ujęta w dwa krótkie akty, „Albumowy Kalendarz Polski Satyryczny”, R. 2: 1895, s. 32-33.

Sienkiewicz Henryk, Teatr. „,Kosa i kamień, przysłowie dramatyczne” J.I. Kraszewskiego, „Okno na pierwszym piętrze”, dram.w 1 akcie” J. Korzeniowskiego, w: „Niwa”, 1875, t. VII, http:// 
www.sienkiewicz.ovh.org/16/040.html [dostęp:10.11.2014].

Skarbek Fryderyk, Co głowa to rozum [felieton], „Pamiętnik Warszawski” 1822, t. 2, s. 389-397.

Skarbek Fryderyk, Co głowa, to rozum, w: Teatr Fryderyka hr. Skarbka, t. 2, Drukarnia Stanisława Strąbskiego, Warszawa 1847, s. 389-419.

Skarbek Fryderyk, Strach ma wielkie oczy czyli Podejrzany. Komedia w trzech aktach przez Fryderyka Hr. Skarbka, Lwów 1877, http://www.sbc.org.pl/dlibra/docmetadata?id=40773 [dostęp: 10.05.2015].

Szpakowska Małgorzata, Wszystkiemu winne Oświecenie, „Dialog”, 1993, t. 38, nr 8, s. 52-58.

Szweykowski Zygmunt, Krytyka teatralna $w$ dobie pozytywizmu wobec aktora i reżysera, „Pamiętnik Teatralny" 1953, t. 2, nr 1 (5), s. 133-160.

Wanicka Agnieszka, Dramat i komedia Teatrów Warszawskich 1868-1880, Wydawnictwo UJ, Kraków 2011.

Witkowski Michał, Znany repertuar teatru wileńskiego 1815-1824, w: tegoż, Świat teatralny młodego Mickiewicza, Państwowy Instytut Wydawniczy, Warszawa 1971, s. 281-320.

Wyka Kazimierz, Wstęp do: Aleksander Fredro, Pisma wszystkie, t. 7: Komedie, Seria druga, oprac. S. Pigoń, Państwowy Instytut Wydawniczy, Warszawa 1958, s. 7-63.

$Z$ teatrzyków ogródkowych [recenzja sztuki Nie miała baba kłopotu Józefa Dłuskiego, wystawionej w teatrzyku „Wodewil”], „Echo Muzyczne, Teatralne i Artystyczne”, R. 5: 1888, nr 254, s. 365.

Zielińska-Grzymała Michalina [pseud. M..a], Kto pod kim dotki kopie, sam w nie wpada. Przystowie dramatyczne w 2 aktach, „Wieczory Rodzinne”, R. 3: 1882, nr 24, s. 370-373 i nr 25, s. 394-396.

Zielińska-Grzymała Michalina [pseud. M..a], Nie wszystko złoto, co się świeci. Obrazek sceniczny w 2 aktach, „Wieczory Rodzinne”, R. 3: 1882, nr 38, s. 598-604 i nr 39, s. 610-614.

Katarzyna Szumska

\section{Proverbes Dramatiques in Polish Nineteenth-century Drama}

\section{(Summary)}

The article presents the nineteenth-century history of the genre called proverbe dramatique a transformation from a theatrical form the origins of which lie in the seventeenth-century dinner games to a work of literature. The sketch presents the origins and the development of the genre, its thematic and formal evolution; characteristic features, including in particular syncretism of genres - combining proverbs with, among others, comedy of manners and romantic comedy, comedy of errors and characters, tragicomedy, farce and sketch - characteristic of this period; the place of dramatic proverbs in the works of selected writers, including, in particular, Jan Chęciński and Aleksander Fredro; and the presence of stage proverbs in Polish drama and in the repertoires of the nineteenth-century theatres.

Keywords: dramatic proverb; stage proverbe; comedy; one-act play; overview of the history of the genre

Słowa kluczowe: proverbe dramatique; przysłowie dramatyczne; przysłowie sceniczne; komedia; jednoaktówka; zarys historii gatunku 